\title{
ANALISIS FAKTOR-FAKTOR YANG MEMPENGARUHI ALIH FUNGSI LAHAN DI KABUPATEN TANJUNG JABUNG TIMUR-INDONESIA
}

\author{
Saad Murdy ${ }^{1)}$, Saidin Nainggolan ${ }^{2)}$ \\ ${ }^{1,2)}$ Dosen Jurusan Agribisnis Fakultas Pertanian Universitas Jambi \\ Email : saidinnainggolan@yahoo.com
}

\begin{abstract}
Abstrak
Penelitian ini bertujuan untuk menganalisis faktor-faktor yang mempengaruhi petani melakukan konversi lahan sawah menjadi perkebunan sawit. Daerah penelitian Kabupaten Tanjung Jabung Timur dengan daerah sampel Kecamatan Geragai yang diambil secara purposive. Ukuran sampel sebanyak 90 petani dan metode penarikan sampel secara snowball Metode analisis menggunakan model analisis logistic binary logit. Dari hasil analisis dapat disimpulkan bahwa Rendahnya produktivitas padi mendorong petani melakukan konversi lahan sawah secara nyata, Petani lahan luas melakukan konversi lahan secara signifikan. Petani yang mempunyai pengalaman baik tentang aspek teknis, lingkungan, dan ekonomi melakukan konversi lahan sawahnya secara signifikan, Penguatan motif ekonomi berpengaruh signifikan terhadap keputusan petani untuk melakukan konversi lahan sawahnya. Petani yang mempunyai sumber pendapatan dari off farm dan non farm berpengaruh terhadap keputusan petani untuk melakukan konversi lahan secara signifikan. Pelemahan kondisi aspek lingkungan memperkuat keputusan petani melakukan konversi lahan secara signifikan. Kondisi aspek teknis yang tidak mendukung usahatani padi mendorong petani melakukan konversi lahan secara signifikan. Untuk mengatasi konversi lahan yang semakin luas diperlukan usaha-usaha memperbaiki aspek lingkungan lahan sawah, aspek teknis dan mengubah pandangan motif ekonomi di kalangan petani. Penguatan ini diharapkan akan meningkatkan produktivitas padi yang lebih menguntungkan setara dengan perkebunan sawit.
\end{abstract}

Kata Kunci: Konversi, Lahan Sawah, Perkebunan Sawit.

\begin{abstract}
This study aims to analyze the factors that influence farmers to convert paddy fields to oil palm plantations. The research area of Tanjung Jabung Timur Regency with the sample area of Geragai District which was taken purposively. The sample size was 90 farmers and the snowball sampling method. The method of analysis used a logistic binary logit analysis model. From the analysis, it can be concluded that low rice productivity encourages farmers to significantly convert paddy fields. Large land farmers carry out significant land conversions. Farmers who have good experience with technical, environmental, and economic aspects have significantly converted their paddy fields. Strengthening economic motives has a significant effect on farmers' decisions to convert their paddy fields. Farmers who have sources of income from off farm and non-farm have a significant effect on farmers' decisions to convert land. The weakening of environmental aspects strengthens farmers' decisions to significantly convert land. The condition of the technical aspects that do not support rice farming encourages farmers to carry out significant land conversion. To deal with the increasingly widespread land conversion, efforts are needed to improve the environmental aspects of paddy fields, technical aspects and change the perspective of economic motives among farmers. This strengthening is
\end{abstract}


expected to increase rice productivity which is more profitable on a par with oil palm plantations.

Key words: Conversion, Paddy Field, Oil Palm Plantation.

\section{PENDAHULUAN}

Secara nasional sumber daya lahan sawah memiliki arti penting dalam memproduksi bahan kebutuhan pangan pokok. Sekitar $90 \%$ produksi padi nasional dihasilkan dari lahan sawah dan sisanya dari lahan kering . Lahan sawah juga mempunyai peranan besar dalam menjaga ketahanan pangan. Namun karena faktor sosial, ekonomi, lingkungan dan aspek teknis lahan sawah banyak mengalami konversi lahan. Konversi yang dilakukan petani adalah peralihan komoditas. Lahan sawah yang dulunya ditanami komoditas padi sekarang banyak ditanami dengan komoditas sawit. Konversi lahan sawah menjadi perkebunan sawit merupakan alih fungsi yang bersifat permanen sehingga tidak mungkin lagi dalam jangka pendek kembali menjadi lahan sawah.

Provinsi Jambi memiliki banyak lahan pertanian produktif, baik persawahan maupun lahan-lahan pertanian lainnya. Beberapa tahun terakhir ini telah terjadi penurunan luas lahan sawah. Sebanyak 12,184 ha lahan sawah telah berkurang di Povinsi Jambi mulai tahun 2013 sampai 2019. Sedangkkan luas lahan perkebunan mengalami peningkatan setiap tahunnya. Jika dibandingkan angka penurunan luas lahan sawah dengan angka peningkatan luas lahan perkebunan kurun waktu tahun 2013 sampai 2019, peningkatan luas lahan perkebunan 12 kali lipat dari penurunan luas lahan sawah, yakni 157,399 ha. Perkebunan di Provinsi Jambi mengalami perkembangan pesat melakukan ekspansi lahan, bukan saja pembukaan lahan baru dari lahan kosong namun juga karena konversi lahan sawah menjadi lahan perkebunan.

Di Provinsi Jambi, Kabupaten Tanjung Jabung Timur memiliki lahan sawah terluas dan dikenal sebagai lumbung padi, kini telah mengalami penurunan luas dan produksi. Penurunan luas lahan mencapai 10,141 ha per tahun. Penurunan produksi 27,583 ton per tahun. Keadaan ini akan memperburuk status ketahanan pangan wilayah dalam jangka panjang. Terjadi konversi penggunaan lahan sawah pada setiap kecamatan . Kecamatan Geragai mengalami penurunan luas lahan sawah sangat besar dibandingkan kecamatan lainnya. Kondisi ini sangat merugikan, karena alih fungsi lahan dapat menyebabkan masalah baru pada masa mendatang. Dalam kaitan ini, penelitian ini bertujuan untuk mengetahui pengaruh faktor sosial, ekonomi, lingkungan dan teknis terhadap konversi lahan sawah menjadi perkebunan sawit.

\section{METODE PENELITIAN}

Penelitian dilaksanakan di Kabupaten Tanjung Jabung Timur dengan daerah sampel Kecamatan Geragai yang diambil secara purposive. Objek penelitian adalah petani yang mengalihkan dan petani yang tidak mengalihkan fungsi lahan sawah menjadi lahan perkebunan sawit.Ukuran sampel sebanyak 90 KK. Metoda pengumpulan data dengan teknik wawancara dengan bantuan kuisioner. Teknik pengambilan sampel adalah dengan snowball

Metode analisis model analisis logistic binary. Fungsi logistic binary adalah suatu deskripsi hubungan variabel independen dengan variabel dependen, dimana variabel dependennya bersifat dikotomis (ya/tidak) . Model logit (ergolong model respon yang menggunakan variabel terikat memiliki probabilitas antara 0 dan 1 . Selain itu, model logit paling sesuai dalam menjelaskan hubungan non linier antara probabilitas dan variabel 
penjelas.Selain itu, pendugaan dengan model logit dapat menentukan besarnya peluang setiap variabel berpengaruh terhadap variabel dependen (Hosmer, DW and Lemeshow, S. 2000) sebagai berikut;.

$$
\mathrm{P}_{\mathrm{i}}=\mathrm{F}\left(\mathrm{Z}_{\mathrm{i}}\right)=\mathrm{F}(\alpha+\Sigma \beta \mathrm{iXi})=\frac{1}{1+\mathrm{e}^{-\mathrm{zi}}}
$$

$\mathrm{Pi}=$ Probabilitas bahwa seorang petani akan mengalihkan atau tidak mengalihkan lahan sawah menjadi lahan kelapa sawit.

$\mathrm{e}=$ Dasar logaritma alami (kira-kira $=2,718)$

$\mathrm{Xi}=$ Variabel penjelas

$\alpha \beta i=$ Parameter yang diestimasi

Rasio Oods (peluang) menyatakan rasio probabilitas (Pi) bahwa seorang petani akan mengalih fungsikan lahan sawahnya dengan probabilitas $(1-\mathrm{Pi})$ bahwa petani tidak mengalihkan lahannya.

$(1-\mathrm{Pi})=\frac{1}{1+\mathrm{e}^{-\mathrm{zi}}}$.

Oleh karena itu,

$\left(\frac{\mathrm{Pi}}{1-\mathrm{Pi}}\right)=\left(\frac{1+\mathrm{e}^{\mathrm{zi}}}{1+\mathrm{e}^{-\mathrm{zi}}}\right)=\mathrm{e}^{\mathrm{zi}}$

Dengan mengambil logaritma natural (Wiryono, A. 2010).

$\mathrm{Zi}=\operatorname{Ln}\left(\frac{\mathrm{Pi}}{1-\mathrm{Pi}}\right)=\alpha+\beta_{1} \mathrm{X}_{1}+\beta_{2} \mathrm{X}_{2}+\cdots+\beta_{m} \mathrm{X}_{\mathrm{m}}$

Jika gangguan dimasukkan ke dalam perhitungan, maka:

$\mathrm{Zi}=\alpha+\sum_{i=1}^{m} \beta i X i+\mu i$

Aplikasi model di atas untuk penelitian ini adalah sebagai berikut :

$Y=b_{0}+b_{1} X_{1}+b_{2} X_{2}+b_{3} X_{3}+b_{4} X_{4}+b_{5} X_{5}+b_{6} X_{6}+d X_{2.1}+d X_{2.2}+d X_{6.1}+d X_{6.2}+e$

Dimana :

$\mathrm{y} \quad=1$ : Mengalihkan lahan padi sawah menjadi perkebunan sawit

$\mathrm{y} \quad=0$ : Tidak mengalihkan lahan padi sawah

$\mathrm{X}_{1} \quad=$ Produktivitas padi $(\mathrm{kg} / \mathrm{ha})$

$\mathrm{X}_{2} \quad=$ Luas kepemilikikan lahan (ha)

$\mathrm{X}_{3} \quad=$ Pengalaman berusahatani (tahun)

$\mathrm{X}_{4} \quad=$ Motif ekonomi (skor)

$\mathrm{X}_{5} \quad=$ Sumber Pendapatan Usahatani Lainnya (Rp)

$\mathrm{X}_{6} \quad=$ Kondisi aspek lingkungan (skor)

$\mathrm{X} 7=$ Kondisi aspek teknis (skor)

\section{HASIL DAN PEMBAHASAN}

\section{Deskripsi Alih Fungsi Lahan}

Alih fungsi lahan sawah menjadi perkebunan sawit disebabkan faktor rendahnya nilai ekonomis lahan sawah $(65,6 \%)$, terbatasnya ketersediaan sumber daya air (irigasi, drainase, atau pompanisasi $(17,8 \%)$ dan tidak adanya larangan untuk alih fungsi lahan sawah (16,6 \%). Berdasarkan faktor penyebabnya, tipologi alih fungsi lahan sawah menjadi perkebunan sawit terbagi menjadi dua, yaitu tipologi (1) dengan kecenderungan alih fungsi lahan tinggi dan tipologi (2) dengan tipologi alih fungsi lahan rendah. Ada sebanyak 64,7 \% petani menyebutkan bahwa kurangnya insentif bagi petani dalam bantuan modal kerja dan sarana produksi, sebanyak 68,3\% petani menyebutkan bahwa tidak adanya normalisasi pada sarana dan prasarana irigasi, dan sebanyak 53,8 \% petani 
tidak adanya buffer zone antara lahan pertanian sawah dan perkebunan sawit terutama perusahaan perkebunan sawit. Pada dasarnya faktor yang menyebabkan konversi lahan padi menjadi perkebunan sawit digolongkan pada tiga aspek, yaitu aspek ekonomis, aspek teknis dan aspek lingkungan. Dari hasil pengolahan data diketahui bahwa sebanyak 71,7 $\%$ petani memutuskan untuk konversi lahan. Pertimbangan petani memutuskan melakukan konversi lahan sangat dipengaruhi o9leh aspek ekonomis $(56,1 \%)$, selanjutnya diikuti oleh aspek lingkungan $(24,4 \%)$ dan aspek teknis $(19,5 \%)$.

Bila dijabarkan dari pengaruh faktor-faktor penyebab, terdapat 14 faktor yang mempengruhi keputusan petani melakukan konversi lahan yang terdiri atas 5 faktor penyebab dari aspek ekonomis, 5 penyebab dari aspek lingkungan dan 4 faktor penyebab dari aspek teknis. Aspek ekonomis terdiri atas (1) harga jual panen padi tergolong rendah terutama saat panen $(13,1 \%),(2)$ panen sawit kontinyu setiap dua minggu sekali $(15,3 \%)$ (3) keuntungan berkebun sawit lebih tinggi (12,5\%) (4) pasar dan harga sawit terjamin $(7,6 \%)$ dan (5) biaya pemeliharaan tanaman sawit lebih rendah (3,6 \%). Aspek lingkungan terdiri atas (1) kecocokan lahan untuk perkebunan sawit $(8,9 \%)$, (2) ancaman hama dan penyakit tanaman padi $(6,8 \%)$, (3) kondisi irigasi tidak mendukung $(4,9 \%)$, (4) posisi tawar petani sawit lebih tinggi $(4,9 \%)$ dan tenaga kerja kebun sawit lebuh sedikit $(3,2 \%)$. Sedangkan aspek teknis terdiri atas (1) tanaman sawit berumur panjang $(11,3 \%)$, (2) proses pasca panen padi membutuhkan waktu, tenaga dan biaya $(2,2 \%),(3)$ tehnik budidaya sawit lebih mudah $(2,3 \%)$, dan (4) lebih mudah pengadaan pupuk tepat waktu jumlah dan harga pada perkebunan sawit $(3,3 \%)$.

\section{Analisis Faktor-Faktor yang Mempengaruhi Alih Fungsi Lahan}

Tujuan dari analisis ini adalah untuk mengetahui apakah variabel produktivitas lahan, luas kepemilikan lahan, pengalaman usahatani, motif ekonomi, sumber pendapatan lain aspek teknis, aspek ekonomi dan aspek lingkungan berpengaruh terhadap konversi fungsi lahan sawah menjadi perkebunan sawit. Hasil dari analisis logistik biner adalah sebagai berikut :

\section{Uji Goodness of Fit $\left(R^{2}\right)$}

Nilai koefisien determinasi $\left(R^{2}\right)$ untuk model logistik binary digunakan nilai Mc Fadden $R^{2}$. Adapun besarnya nilai Mc Fadden $R^{2}=0,683614$, artinya nilai presisi model regresi logistik yang digunakan adalah $68,36 \%$. Nilai keputusan petani dalam konversi lahan sawah menjadi perkebunan sawit dapat dijelaskan secara simultan oleh variabel independen yang terdapat pada model sebesar $68,36 \%$ dan sisanya sebesar $31,64 \%$ dipengaruhi faktor lainnya yang tidak terdapat pada model. Nilai LR stat $=56,85$ dengan prob.. (LR stat $=0,0000)<\alpha(0,01)$, artinya berbeda sangat nyata. Model mampu menjelaskan secara sangat nyata bahwa konversi lahan sawah menjadi perkebunan sawit secara simultan dipengaruhi produktivitas padi, luas lahan, pengalaman, sumber pendapatan lainnya, motif ekonomi, motif lingkungan dan motif teknis.

Nilai peluang model regresi binary logit faktor-faktor yang mempengaruhi konversi lahan sawah menjadi perkebunan sawit adalah sebagai berikut:

$$
\begin{aligned}
& \mathrm{P}\left(x_{i}\right)=\frac{1}{1+e^{-z i}} \\
& =0,785=78,5 \%
\end{aligned}
$$

Jika nilai peluang $\mathrm{P}(\mathrm{Xi})$ berkisar 40 - $60 \%$ maka variabel independen secara simultan dalam model telah dianggap baik sebagai penjelas (Gujarati, 2006). Dalam penelitian ini produktivitas padi, luas lahan, pengalaman, pendapatan luar usahatani, motif ekonomi, 
aspek lingkungan dan aspek teknis secara simultan berpengaruh terhadap konversi fungsi lahan sawah menjadi perkebunan sawit dengan besarnya peluang 78,5\%

\section{Hasil Estimasi Regresi Logistik Biner Logit}

Analisis regresi logistik biner digunakan untuk menguji variabel independen terhadap variabel dependen yang dalam hal ini adalah keputusan petani untuk mengalih fungsikan lahan sawahnya menjadi lahan kelapa sawit. Hasil estimasi regresi binary logit faktor-faktor yang mempengaruhi konversi lahan sawah menjadi perkebunan sawit dapat dilihat Tabel 1.

Tabel 1. Hasil Regresi Regresi Binary Logit Faktor-Faktor yang Mempengaruhi Alih Fungsi Lahan di Daerah Penelitian Tahun 2020

\begin{tabular}{|c|c|c|c|c|c|}
\hline Variable & Coefficient & Std. Error & z-Statistic & Prob. & $\mathrm{P}\left(\mathrm{x}_{\mathrm{i}}\right)$ \\
\hline $\begin{array}{l}\text { PRODUKTIVITAS } \\
\text { PADI (X1) }\end{array}$ & -0.824204 & 0.428607 & -1.922985 & 0.0243 & 0,4386 \\
\hline $\begin{array}{l}\text { LUAS LAHAN } \\
\text { (X2) }\end{array}$ & 0.990923 & 0.407105 & 2.434071 & 0.0149 & 2,6935 \\
\hline $\begin{array}{l}\text { PENGALAMAN UT } \\
\text { (X3) }\end{array}$ & 0.325521 & 0.171333 & 1.899932 & 0.0274 & 1,3847 \\
\hline $\begin{array}{l}\text { MOTIF EKONOMI } \\
(\mathrm{X} 4)\end{array}$ & 0.090297 & 0.044613 & 2.023999 & 0.0327 & 1,0943 \\
\hline $\begin{array}{l}\text { PEND.LUAR PADI } \\
\text { (X5) }\end{array}$ & 0.910981 & 0.359626 & 2.533137 & 0.0254 & 2,4864 \\
\hline $\begin{array}{l}\text { LING. UT.PADI } \\
\text { (X6) }\end{array}$ & -0.263393 & 0.106003 & -2.484761 & 0.0343 & 0,7685 \\
\hline $\begin{array}{l}\text { ASPEK TEKNIS } \\
(\mathrm{X} 7)\end{array}$ & 0,314362 & 0,102524 & 3,06622 & 0,0245 & 1,3692 \\
\hline $\mathrm{C}$ & -1.293289 & 3.483037 & -0.371311 & & 0,7104 \\
\hline McFadden R-squared & 0.683419 & \multicolumn{4}{|c|}{ Mean dependent var } \\
\hline S.D. dependent var & 0.504219 & \multicolumn{4}{|c|}{ S.E. of regression } \\
\hline Akaike info criterion & 0.672208 & \multicolumn{2}{|c|}{ Sum squared resid } & \multicolumn{2}{|r|}{4.058521} \\
\hline Schwarz criterion & 0.916548 & \multicolumn{2}{|c|}{ Log likelihood } & \multicolumn{2}{|r|}{-13.16624} \\
\hline Hannan-Quinn criter. & 0.767783 & \multicolumn{2}{|c|}{ Deviance } & \multicolumn{2}{|r|}{26.33247} \\
\hline Restr. Deviance & 83.17766 & \multicolumn{2}{|c|}{ Restr. log likelihood } & \multicolumn{2}{|c|}{-41.58883} \\
\hline LR statistic & 56.84519 & \multicolumn{2}{|c|}{ Avg. log likelihood } & \multicolumn{2}{|r|}{-0.219437} \\
\hline Prob(LR statistic) & 0.000000 & & & & \\
\hline
\end{tabular}




\begin{tabular}{|llll|}
\hline Obs with Dep $=1$ & 50 & Total obs & 90 \\
\hline Obs with Dep $=0$ & 40 & & \\
\hline
\end{tabular}

Dari tabel 1 dapat dijelaskan pengaruh parsial faktor-faktor yang mempengaruhi konversi lahan sawah menjadi perkebunan sawit sebagai berikut :

Produktivitas Padi $\left(X_{I}\right)$ Nilai koefisien regresi logistik $X_{1}$ bertanda negatif menunjukkan bahwa terdapat pengaruh yang berbanding terbalik antara variabel produktivitas padi terhadap keputusan petani untuk konversi lahan sawah menjadi perkebunan sawit dengan prob. $0,0243<\alpha(0,05)$ terdapat beda nyata. Hal ini berarti produktivitas padi yang rendah berpengaruh nyata terhadap terjadinya konversi lahan sawah menjadi perkebunan sawit . Peluang petani melakukan konversi lahan sawahnya menjadi perkebunan sawit adalah sebesar 0,439 (43,9\%) kali dari sebelunnya. Dengan kata lain jika produktivitas padi semakin berkurang dari sebelumnya maka peluang petani dari tidak mengalihkan menjadi mengalihkan bertambah sebesar 0,439 kali. Hal ini sejalan dengan Nadia (2013) bahwa $73,6 \%$ petani melakukan alih fungsi lahan karena produktivitas padi $<2$ ton/ha, sedangkan 26,4 \% petani produktivitas padi $2-3,0$ ton/ha. Penelitian ini menunjukkan bahwa semakin rendah produktivitas padi semakin besar peluang petani melakukan konversi lahan sawah menjadi perkebunan sawit.

Luas Lahan $\left(\boldsymbol{X}_{2}\right)$ Luas lahan petani rata-rata seluas 2,65 ha, ada sebanyak 48,3\% petani memliki luas lahan $1,0-<2,0$ ha, sebanyak $25,4 \%$ petani dengan luas lahan 2,1 - 3,0 ha dan sebanyak 26,3\% petani dengan luas $>3,5$ ha. Petani dengan luas lahan tergolong luas $>$ 2,65 lebih cepat melakukan konversi lahan Nilai koefisien regresi logistik $\mathrm{X}_{2}$ bertanda positif menunjukkan bahwa terdapat pengaruh yang berbanding lurus antara luas lahan terhadap keputusan petani untuk konversi lahan sawah menjadi perkebunan sawit dengan prob. $0,0149<\alpha(0,05)$ terdapat beda nyata. Hal ini berarti lahan luas berpengaruh nyata terhadap terjadinya konversi lahan. Peluang petani untuk melakukan konversi lahan sebesar 2,69 kali dari sebelumnya. Sejalan dengan hasil penelitian Adlaida et.al (2017) yang menyatakan bahwa dengan tingkat sig.0,0149 $<\alpha(0,05)$, terdapat beda nyata, bahwa lahan luas berpengaruh signifikan terhadap pengambilan keputusan petani untuk melakukan konversi lahan.

Pengalaman Berusahatani $\left(\boldsymbol{X}_{3}\right)$ Peluang petani mengalih fungsikan lahan sawahnya menjadi perkebunan sawit sebesar 1,38 kali dari sebelumnya. Hal ini berarti apabila terjadi penguatan pengalaman berusahatani dari sebelumnya maka peluang petani dari tidak mengalihkan menjadi mengalihkan sebesar 1,38 kali Nilai koefisien regresi logistik $\mathrm{X}_{3}$ bertanda positif menunjukkan bahwa terdapat pengaruh yang berbanding lurus antara pengalaman berusahatani terhadap keputusan petani untuk beralih ke perkebunan sawit, dengan prob. $0,0274<\alpha(0,05)$, terdapat beda nyata. Dengan kata lain, pengalaman berusahatani berpengaruh nyata terhadap konversi lahan dari sebelumnya. Petani yang mempunyai pengalaman baik tentang aspek teknis, lingkungan, ekonomi dan sosial relatif cepat melakukan konversi Skor pengalaman petani yang mempengaruhi konversi lahan; aspek teknis berkisar 70,5 \% (kategori tinggi) aspek lingkungan sebesar 63,3\% (kategori sedang), aspek sosial sebesar 48,3 \% (kategori rendah) dan aspek ekonomi sebesar 78,2 $\%$ (kategori tinggi). Sejalan dengan hasil penelitian Asep, N (2015) bahwa pengalaman berbeda nyata dengan sig. 0,0274 $<\alpha(0,05)$, artinya faktor pengalaman berpengaruh signifikan terhadap pengambilan keputusan petani . 
Motif Ekonomi $\left(\boldsymbol{X}_{4}\right)$ Nilai koefisien regresi logistik $\mathrm{X}_{4}$ bertanda positif menunjukkan bahwa terdapat pengaruh yang berbanding lurus antara motif ekonomi terhadap keputusan petani untuk konversi lahan sawah menjadi perkebunan sawit, dengan prob.0,0327< $\alpha$ $(0,05)$. Hal ini berarti penguatan motif ekonomi secara nyata mempercepat terjadinya konversi lahan Apabila terjadi penguatan motif ekonomi dari sebelumnya maka peluang petani untuk konversi sebesar 1,10 kali (110\%). Nilai aspek motif ekonomi bersumber dari; (1) panen sawit kontinu setiap dua minggu sekali (31,4\%), (2) keuntungan berkebun sawit lebih tinggi (20,3\%), (3) biaya pemeliharaan sawit lebih murah $(18,3 \%)$, (4) hemat penggunaan tenaga kerja $(10,5 \%)$, (5) pasar dan harga jual sawit lebih menguntungkan dari padi terutama pada saat panen Penelitian Siti Marlina (2004), bahwa petani yang beralih memiliki skor tinggi 16-21 sebesar 90,48 \% sedangkan untuk petani yang tidak beralih memiliki skor sedang 10-15 sebesar 50\%, perbedaan motif ekonomi dapat mengakibatkan perbedaan keputusan petani untuk beralih atau tidak beralih. Motif ekonomi berpengaruh nyata terhadap keputusan petani untuk beralih ataupun tidak beralih fungsi lahan (Saili, I dan Heru, P, 2012).

Sumber Pendapatan Usatani Lainnya $\left(X_{5}\right)$, petani mempunyai sumber pendapatan dari on farm sebanyak 92,6\% petani, off farm sebanyak 56,5\% petani dan non farm sebanya $33,7 \%$ besarnya peluang petani mengalih fungsikan lahan sawahnya menjadi perkebunan sawit karena adanya peningkatan sumber pendapatan usahatani lainnya adalah sebesar 2,49 kali dari sebelumnya. Nilai koefisien regresi logistik $X_{5}$ bertanda positif menunjukkan bahwa terdapat pengaruh yang berbanding lurus antara sumber pendapatan usahatani lainnya terhadap keputusan petani untuk beralih ke perkebunan sawit, dengan prob. $0,0254<\alpha(0,05)$. terdapat beda nyata, artnya peningkata pendapatan dari sumber lain akan berpengaruh terhadap konversi lahan secara signifikan. Apabila petani mempunyai kemampuan untuk membiayai kebutuhan keluarga dari usaha off farm dan non farm maka akan mempercepat konversi (replanting), (Adlaida, et.al.2016).

Kondisi Aspek Lingkungan $\left(\boldsymbol{X}_{\boldsymbol{\sigma}}\right) \quad$ Nilai koefisien regresi logistik motif karena aspek lingkungan bertanda negatif menunjukkan adanya pengaruh yang berbanding terbalik antara motif lingkungan terhadapkeputusan konversi lahan sawah menjadi perkebunan sawit, dengan prob. $0,0343<\alpha(0,05)$. Hal ini berarti pelemahan aspek lingkungan secara nyata mempercepat terjadinya konversi. Peluang petani untuk melakukan konversi lahan sebesar 0,772 kali atau peningkatan keputusan petani melakukan konversi lahan sebesar $77,2 \%$ dari sebelumnya. Nilai skor aspek lingkungan bersumber dari ; kesesuaian lahan sawah untuk perkebunan sawit (52,3\%), kondisi irigasi tidak mendukung (20,6 \%), ancaman hama dan penyakit kelapa sawit lebih rendah (16,5\%), status sosial petani sawit lebih tinggi $(5,7 \%)$ dan tenaga kerja kebun sawit lebih sedikit (4,9\%). Saili, I dan Heru, P (2012), bahwa kondisi lahan yang tidak mendukungi mempengaruhi petani melakukan pengalihan fungsi lahan dari usahatani padi menjadi perkebunan sawit sebanyak 76,15\% petani dan kondisi lahan yang masih produktif sebanyak $28,85 \%$ petani . Kondisi aspek lingkungan lahan yang tidak produktif lagi untuk ditanamai padi mengakibatkan petani melakukan pengalihan fungsi lahan kelahan kelapa sawit (astuti, P.U, Wibawa, W dan Ishak, A, 2011).

Kondisi Aspek Teknis (X7). Nilai koefisien regresi logistik aspek teknis (motif teknis) bertanda positif,artinya penguatan motif teknis akan mendorong petani melakukan konversi lahan sawah menjadi perkebunan sawit, dengan prob. 0,0245 $<\alpha(0,05)$. Hal ini berarti penguatan motif karena alasan teknis secara nyata mempercepat terjadinya 
konversi lahan. Peluang petani untuk melakukan konversi sebesar 1,37 kali dari sebelumnya atau peningkatan untuk melakukan konversi sebesar $137 \%$ dari sebelumnya. Nilai skor aspek teknis bersumber dari ; umur produktif kelapa sawit lama $(42,4 \%)$, teknik budidaya kelapa sawit mudah $(45,2 \%)$, proses panen dan jual mudah $(5,6 \%)$ dan pengadaan saprodi sesuai kebutuhan lebih mudah $(6,8 \%)$.

\section{SIMPULAN DAN IMPLIKASI KEBIJAKAN}

Rendahnya produktivitas padi mendorong petani melakukan konversi lahan sawah secara nyata, dan lahan yang produktivitas tinggi tidak mengalami konversi, luas lahan $(>2,65$ ha) lebih cepat mengalami konversi dibanding lahan sempit $(<2$ ha). Petani yang mempunyai pengalaman baik tentang aspek teknis, lingkungan, ekonomi dan sosial relatif cepat melakukan konversi, percepatan motif ekonomi dari sebelumnya maka peluang petani untuk konversi lahan semakin besar, terdapat pengaruh motiv ekonomi terhadap keputusan petani untuk melakukan konversi lahan sawahnya secara signifikan.

Petani yang mempunyai sumber pendapatan dari off farm dan non farm berbanding lurus dengan keputusan petani untuk melakukan konversi lahan secara signivikan. Pelemahan kondisi aspek lingkungan memperkuat keputusan petani melakukan konversi lahan secara signifikan. Kondisi aspek teknis yang tidak mendukung usahatani padi mendorong petani melakukan konversi lahan secara signivikan. Untuk melakukan pembatasan terjadinya konversi lahan yang semakin besar maka perlu usaha-usaha memperbaiki aspek lingkungan lahan sawah, aspek teknis dan perbaikan pandangan motif ekonomi di kalangan petani. Penguatan ini diharapkan terjadi peningkatan produktivitas padi yang lebih menguntungkan setara dengan perkebunan sawit.

\section{DAFTAR PUSTAKA}

Asep Nanang. 2014. Faktor - Faktor yang Mempengaruhi Keputusan Alih Fungsi Lahan Kebun Karet Menjadi Kebun Sawit Program Studi Penyuluhan dan Komunikasi Pertanian. Universitas Jambi. Jambi

Astuti, P.U, Wibawa, W dan Ishak, A. 2011- Faktor-faktor yang Mempengaruhi Alih Fungsi Lahan Pangan Menjadi Kelapa Sawit di Bengkulu. Kasus Petani di Desa Kungkai Baru. Prosiding Seminar Nasional Budidaya Pertanian, Faperta Unib, Bengkulu.

Gujarati, D. 2006. Basic Econometric. Fourth Edition. MC-Graw Hill, New York.

Hosmer, DW and Lemeshow, S. 2000. Applied Regression Logistic. Second Edition, Jhon Wiley and Sons, Inc. Canada.

Malik, A. et.al 2017. The Study of Farmers Economic Abilities in Palm Plantation in Rural Regency of Muaro Jambi. RJOAS 10(70) October 2017. DOI. https//doi.org/10-18551/rjoas.

Marlina, Siti. 2004. Faktor-faktor yang Melatar belakangi Keputusan Petani Beralih dari Usahatani Karet Rakyat ke Kelapa Sawit di Desa Sungai Gelam Kecamatan Kumpeh Ulu Kabupaten Muaro Jambi. Universitas jambi.

Rusastra, IW., dan G.S, Budhi. 1997. Konversi Lahan Pertanian dan Strategi Antisipatif dalam Penanggulangannya. Jurnal Penelitian dan Pengembangan Pertanian. Volume XVI, Nomor 4: 107-113. Badan Penelitian dan Pengembangan Pertanian, Departemen Pertanian. Bogor 
Jurnal Manajemen Terapan dan Keuangan (Mankeu) Vol. 9 No. 03, Desember 2020 P-ISSN: 2252-8636, E-ISSN: 2685-9424

Saili, Ikhlas., dan Heru Purwadio. 2012. Pengendalian Alih Fungsi Lahan Pertanian Sawah Menjadi Perkebunan Kelapa Sawit si Wilayah Kabupaten Siak-Riau.Teknik Perencanaan Wilayah dan Kota Vol.1,No.1. Riau

Sudaryadi, A. 2012. Analisis Pendapatan Petani Kelapa Sawit dengan Sistem Perkebunan Inti Rakyat (PIR) di Desa Mulya Jaya Kecamatan Mesuji Raya. Kabupaten Komering Ilir. (http://repository.riba.ac.id diakses 14 Desember 2016). 